\title{
KORELASI ANTARA HASIL BELAJAR DAN METAKOGNISI SISWA SEKOLAH DASAR DI NANGA PINOH, KALIMANTAN BARAT
}

\author{
Rindah Permatasari \\ STKIP Melawi \\ e-mail: rindahpermatasari@gmail.com
}

\begin{abstract}
The low student learning outcomes are caused by various aspects, one of them is student awareness of the importance of learning. The purpose of this study was to analyze the correlation between students' science learning outcomes and metacognitive skills in elementary school students in Nanga Pinoh. This research is a quantitative study using One Group Pretest-Posttest design. Data was taken from 67 students in 3 State Elementary Schools, namely SDN 28, SDN 06, and SDN 03 Nanga Pinoh. The instruments used were test questions and the Metacognitive Skills Questionnaire. Data were analyzed descriptively quantitatively. The results of data analysis using Pearson Product Moment Correlation shows that there is a significant positive relationship between student academic procrastination and student cognitive ability with the acquisition (rcount) $=0.993$ at the significance level of 0.00. This means that the higher the level of metacognitive skills of students, the student learning outcomes will also increase. The coefficient of determination shows 0.98 or 98\%, this means that student learning outcomes are determined by the level of metacognitive skills of students, while $2 \%$ of student learning outcomes are determined by other factors such as health, the presence or absence of problems and others.
\end{abstract} Keywords: correlation, learning outcomes, metacognitive skills.

\section{A. Pendahuluan}

Pengembangan semua aspek kepribadian manusia yang mencakup pengetahuan, nilai, sikap, dan keterampilan untuk membentuk pribadi suatu individu yang lebih baik adalah tujuan dari adanya pendidikan. Pernyataan tersebut tertuang dalam Undangundang No.20 tahun 2003 pada Bab 2 pasal 3 dan Peraturan Menteri Pendidikan Nasional Republik Indonesia Nomor 23 tahun 2016 yang menyatakan bahwa salah satu tujuan pendidikan adalah mengembangkan potensi peserta didik agar menjadi manusia yang memiliki kekuatan spiritual keagamaan, pengendalian diri, kepribadian akhlak serta keterampilan dan mampu mengembangkan budaya belajar untuk pembelajaran diri (Long life education). Dalam hal ini, pendidikan diharapkan bukan hanya meningkatkan hasil belajar kognitif namun membudayakan belajar setiap saat untuk bekal menapaki dikehidupan.

Hasil belajar adalah perubahan kemampuan yang diperoleh siswa setelah melaksanakan proses pembelajaran. Mujiono (2013) menyatakan bahwa hasil belajar adalah buah dari hasil interaksi belajar dan mengajar. Lebih jauh, Hamalik (2003) 
menambahkan, hasil belajar bukan hanya hasil interaksi, namun merupakan tingkat penguasaan seseorang terhadap suatu materi oleh pelajar setelah mengikuti proses belajar mengajar yang telah disesuaikan dengan tujuan pembelajaran. Hasil belajar dipengatuhi oleh banyak faktor salah satunya adalah faktor kesadaran dalam belajar. Slameto (2010) mempertegas pernyataan tersebut, bahwa memang benar bahwa salah satu faktor internal yang dapat mempengaruhi pembelajaran adalah faktor psikologi yang kaitannya dengan metakognisi.

Kemampuan untuk mengatur dan mendidik diri sendiri dalam suatu aktivitas atau kegiatan belajar termasuk dalam metakognitif. Metakognitif atau metakognisi adalah pemantauan dan pengendalian pikiran (Yamin, 2013). Pembelajaran berbasis metakognitif diharapkan dapat membentuk siswa yang mandiri, mampu merencanakan, memonitoring dan mengevaluasi pembelajaran, membentuk siswa yang berkarakter, serta meningkatkan hasil belajar mahasiswa. Pernyataan tersebut sejalan dengan hasil penelitian Fery (2015), Kemandirian belajar siswa yang mendapatkan pembelajaran dengan pendekatan metakognitif berbeda secara signifikan dibandingkan dengan siswa yang mendapatkan pembelajaran konvensional. Yoel (2016) menambahkan bahwa setelah diterapkan strategi pembelajaran metakognitif berbasis tutor sebaya terjadi peningkatan hasil belajar matematika siswa

Pernyataan dan hasil peneilitan tentang metakognitif di atas menunjukan pentingnya keterampilan metakognitif kepada siswa. Siswa yang terampil dalam belajar dan memiliki

keterampilan metakognitif cenderung mampu untuk merancang, memantau, merefleksikan proses belajar, sehingga akan terbentuk pribadi yang lebih percaya diri, mandiri dan dapat meningkatkan hasil belajar. Salah satu manfaat metakognitif bagi siswa adalah pada pemantau diri dan tanggung jawab pada proses belajar siswa. Hal ini sesuai dengan pernyataan Howard (2004) yang menyatakan keterampilan metakognitif memegang peranan penting pada banyak tipe aktivitas kognitif termasuk pemahaman, komunikasi, perhatian, ingatan dan pemecahan masalah.

Rumusan masalah dalam penelitian ini adalah bagaimanakah korelasi antara hasil belajar siswa dengan keterampilan metakognitif siswa Sekolah Dasar di Nanga Pinoh. Tujuan penelitian secara adalah untuk menganalisis korelasi antara hasil belajar siswa dengan keterampilan metakognitif siswa Sekolah Dasar di Nanga Pinoh.

Penelitian mengenai korelasi antara hasil belajar siswa dengan keterampilan metakognitif siswa Sekolah Dasar di Nanga Pinoh belum pernah dikembangkan di Nanga Pinoh, Kabupaten Melawi. Penelitian ini penting dilakukan melihat apakah keterampilan kognitif berkorelasi terhadap hasil belajar siswa. Peneliti berharap dengan keberhasilan penelitian ini dapat menjadi motivasi untuk peneliti lain mengembangkan strategi pembelajaran dan dasar peneliti lain dalam mengembangkan penelitian lanjutan. 
Keterampilan metakognitif adalah keterampilan pengelolaan diri dalam belajar dan menyelesaikan tugas yang mencangkup bagaimana sebaiknya belajar dilakukan, apa yang sudah dan belum diketahui yang terdiri atas perencanaan pembelajaran, monitoring dan evaluasi pembelajaran ( Taccasu, 2008; Rindah, 2016). Indikator keterampilan metakognitif yang dapat diamati meliputi mengidentifikasi tugas, mengawasi kemajuan pekerjaan, mengevaluasi kemajuan, memprediksi hasil yang diperoleh (Rindah, 2016). Keterampilan metakognitif diharapkan dapat meningkatkan kemampuan akademik dan menurunkan prokrastinasi dengan bantuan modul biolgi dasar berbasis berbasis keterampilan metakognitif. Modul biologi dasar berbasis keterampilan metakognitif merupakan bahan ajar yang berisi materi, kegiatan belajar, serta lembar perencanaan, monitoring dan evaluasi keterampilan metakognitif.

Hasil belajar siswa adalah perubahan kemampuan kognitif siswa dari yang tidak tahu menjadi tahu dan dapat dilihat dari peningkatan nilai setelah mengikuti suatu proses pembelajaran. Kemampuan yang diperoleh siswa setelah mengikuti proses pembelajaran yang dijabarkan dalam 6 aspek yaitu pengetahuan, pemahaman,aplikasi, analisis, evaluasi, dan kreasi (Dimyati, 2013). Kemampuan kognitif setiap anak berbeda dipengaruhi oleh faktor dari dalam diri (psikologi dan jasmaniah) dan faktor yang terdapat diluar diri individu (keluarga, sekolah, masyarakat) (Sugihartono, 2007). Indikator kemampuan kognitif yang akan diteskan kepada mahasiswa meliputi tingkatan kognitif pengetahuan (C1) hingga analisis (C4).

\section{B. Metode}

Jenis penelitian ini adalah penelitian kuantitatif dan desain yang digunakan adalah Pre-Exsperimental. Desain ini belum merupakan eksperimen sesungguhnya, sehingga masih terdapat variabel luar yang ikut berpengaruh terhadap terbentuknya variabel dependen, jadi hasil eksperimen bukan semata-mata dipengaruhi oleh variabel independen. Pada tipe One-Group Pretest-Posttest Designs ini terdapat pretest, sebelum diberikan perlakuan. Dengan demikian hasil perlakuan dapat diketahui lebih akurat, karena dapat membandingkan dengan keadaan sebelum diberi perlakuan (Sugiyono, 2016). Berikut pola dari desain one-group pretest posttest

$$
\begin{array}{|lll|}
\hline 0_{1} & \mathrm{X} \quad 0_{2} \\
\hline
\end{array}
$$

Keterangan :

$$
\text { Gambar 1. Desain One Group Pretest Posttest Design }
$$

$0_{1} \quad=$ Pretest

$\mathrm{O}_{2} \quad=$ Posttest

$\mathrm{X}=$ Perlakuan (treament) yaitu penerapan modul biologi berbasis keterampilan metakognitif

Penelitian ini dilakukan di 3 Sekolah Dasar Nanga Pinoh, Melawi-Kalimatan Barat pada tahun ajaran 2018-2019. Penelitian dilaksanakan dalam tiga tahap yaitu 
tahap perencanaan pada bulan Februari-Maret. Pada tahapan ini peneliti melakukan observasi awal, pembuatan perangkat pembelajaran, validasi perangkat dan persiapan penelitian. Tahapan kedua yaitu pelaksanaan penelitian yang dilaksanakan pada bulan April-Mei di 3 Sekolah Dasar di Nanga Pinoh sesuai dengan perencanaan diawal. Pada tahap akhir, data yang diperoleh dianalisis dan dilakukan pelaporan.

Populasi dalam penelitian ini adalah siswa-siswi Sekolah Dasar Negeri di Nanga Pinoh. Jumlah sample dalam penelitian ini adalah 67 siswa-siswi kelas 4 di 3 sekolah dasar yaitu SDN 28, SDN 03, dan SDN 06 Nanga Pinoh. Teknik pengambilan sampel yang digunakan dalam penelitian ini adalah teknik cluster sampling berjenjang. Sampel dalam penelitian ini yaitu siswa-siswi di 3 Sekolah Dasar Negeri di Nanga Pinoh.

Menurut Arikunto (2010) mengatakan teknik pengumpulan data adalah cara-cara yang dapat dipergunakan oleh penulis untuk mengumpulkan data. Dalam penelitian ini teknik pengumpulan data yang dipergunakan adalah tes dan angket. Instrumen penelitian yang dipergunakan pada penelitian ini adalah soal tes kemampuan kognitif (Pretest dan Posttest) dan angket prokrastinasi keterampilan metakognitif siswa.Data yang diperoleh akan dianalisis dengan menggunakan analisis Korelasi Product Moment Pearson yang dihitung dengan menggunakan rumus :

$$
r_{x y}=\frac{N \sum x y-\left(\sum x\right)\left(\sum y\right)}{\left.\left.\sqrt{\left\{N \sum x^{2}\right.}-\left(\sum x\right)^{2}\right\} N \sum y^{2}-\left(\sum y\right)^{2}\right\}}
$$

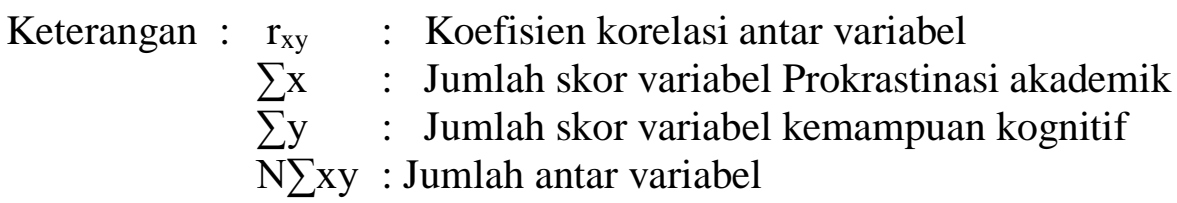

Signifikansi koefisien korelasi bernilai positif jika nilai rxy hitung lebih besar dari pada nilai rxy tabel pada taraf signifikasi 5\% dan 1\% (Sudijono, 2010). Setelah dilakukan analisis data untuk melihat koefisien korelasi, selanjutnya akan dilihat Koefisien Determinasi, yang besarnya adalah kuadrat dari koefisien korelasi $\left(\mathrm{r}^{2}\right)$. Koefisien ini disebut koefisien penentu, karena varians yang terjadi pada variabel dependen dapat dijelaskan melalui varians yang terjadi pada variabel independen.

\section{Hasil dan Pembahasan}

Ketik Teks disini dengan font Times New Roman 12pt, spasi 1,15 dan dalam satu kolom. Subbab ini berisi paparan hasil analisis yang berkaitan dengan pertanyaan penelitian. Setiap hasil penelitian harus dibahas. Pembahasan berisi pemaknaan hasil penelitian dengan teori dan/atau hasil penelitian sejenis. 
Analisis Korelasi Hasil Belajar terhadap Keterampilan Metakognitif Siswa Sekolah Dasar di Nanga Pinoh bertujuan untuk melihat hubungan sebab akibat antara Hasil Belajar terhadap Keterampilan Metakognitif Siswa. Dua variabel dikatakan berkorelasi apabila terdapat perubahan pada variabel satu dan akan diikuti oleh variabel lainnya secara teratur dengan arah yang sama (korelasi positif) atau berlawanan (korelasi negatif). Hasil analisis korelasi hasil belajar terhadap keterampilan metakognitif siswa dengan menggunakan Pearson Product Moment Correlation ditunjukkan pada Tabel 1 .

Siswa

Tabel 1. Korelasi Hasil Belajar terhadap Keterampilan Metakognitif

\begin{tabular}{|c|c|c|c|c|c|c|c|}
\hline & $\mathbf{X}$ & $\mathbf{Y}$ & $\mathbf{x}$ & $\mathbf{y}$ & $\mathbf{x}^{\wedge}$ & $\mathbf{y}^{\wedge}$ & $\mathbf{x y}$ \\
\hline Jumlah & 5310 & 857 & 1680.00 & 246 & 136000 & 2896 & 19700 \\
\hline Rata-rata & 79.25 & 12.79 & - & - & & & \\
\hline & & & & & \multicolumn{2}{|c|}{19845.81} & \\
\hline \multicolumn{5}{|c|}{ Rxy } & \multicolumn{2}{|c|}{0.993} & \\
\hline \multicolumn{5}{|c|}{$\mathbf{D}\left(\mathbf{r}^{\wedge}\right)$} & \multicolumn{2}{|c|}{0.985} & \\
\hline
\end{tabular}

Berdasarkan hasil uji analisis statistik nonparametrik dengan Pearson Product Moment Correlation diketahui bahwa indeks korelasi antara hasil belajar terhadap keterampilan metakognitif siswa sebesar 0.993, lebih besar dari pada angka indeks korelasi tabel tingkat signifikasi $5 \%$ dan $1 \%$ untuk $\mathrm{N}=65$ yaitu 0.244 dan 0.317 , sehingga dapat disimpulkan bahwa terdapat hubungan korelasi positif antara hasil belajar terhadap keterampilan metakognitif siswa. Artinya semakin tinggi nilai siswa maka semakin tinggi pula tingkat keterampilan metakognitifnya. Hasil penelitian yang peneliti temukan berbanding lurus dengan penelitian sebelumnya, Yusnaeni Ganing (2015), dan Yustina Iin (2012) dalam hasil penelitiannya mengatakan bahwa bahwa ada korelasi antara keterampilan metakognitif dengan hasil belajar siswa. Adanya hubungan antara hasil belajar siswa dengan keterampilan metakognitif menunjukan bahwa semakin tinggi tingkat keterampilan metakognitif siswa atau kesadaran siswa dalam belajar, maka hasil belajar yang akan dicapai juga akan semakin tinggi atau semakin meningkat. Keterampilan metakognitif berkaitan dengan psikologis atau mental seseorang. Seseorang yang memiliki kesadaran akan pentingnya belajar, cenderung merasa belajar adalah suatu hal yang menyenangkan. Slameto (2010) dan Sugihartono (2007), menjelaskan bahwa salah satu faktor yang mempengaruhi proses pembelajaran adalah faktor internal yang salah satunya adalah faktor psikologis. Faktor psikologis berkaitan dengan intelegensi atau kecerdasan, perhatian, minat, bakat, motif, 
kematangan dan kesiapan. Sehingga seseorang yang memiliki metakognisi yang tinggi akan berbanding lurus dengan hasil belajar yang dimiliki.

Koefisien determinasi menunjukan 0.98 atau 98\%, hal ini diartikan bahwa hasil belajar siswa ditentukan oleh tingkat keterampilan metakognitif siswa, sedangkan $2 \%$ hasil belajar siswa ditentukan oleh faktor lain seperti kesehatan, ada tidaknya masalah dan lain-lain. Tinggi rendahnya hasil belajar siswa tidak hanya dipengaruhi oleh metakognisi atau keterampilan metakognitif siswa. Slameto (2010) dan Sugihartono (2007), menambahkan bahwa ada dua faktor yang mempengaruhi hasil belajar siswa yaitu faktor internal atau faktor dari dalam siswa dan faktor ekternal atau faktor dari luar siswa. Faktor internal atau faktor dari dalam siswa terdiri faktor psikologi (intelegensi atau kecerdasan, perhatian, minat, bakat, motif, kematangan dan kesiapan) dan jasmaniah(kesehatan dan cacat bawaan) sedangkan faktor ekternal atau faktor dari luar terdiri dari faktor keluarga, sekolah dan masyarakat.

Orang tua memiliki peran penting dalam mengembangkan semua potensi dan kompetenasi yang dimiliki oleh anak. Orang tua yang memperhatikan pendidikan anak mereka, cenderung untuk memiliki anak yang berprestasi jika dibandingkan dengan orang tua yang tidak memperhatikan pendidikan anak mereka. Rika (2017) dari hasil penelitiannya yang berjudul Hubungan Peran Orang Tua terhadap Prestasi Belajar Anak Kelas V di SD Al Azhar Pekanbaru, menjelaskan bahwa terdapat hubungan peran orangtua terhadap prestasi siswa kelas 5 di SD Al Azhar Syifabudi Pekanbaru tahun 2012. Selain faktor orang tua, faktor lingkungan luar seperti teman sebaya juga mempengaruhi hasil belajar siswa. Ni Putu Suyanita (2016) melalui hasil penelitiannya, menambahkan terdapat hubungan yang signifikan antara peran orangtua dan teman sebaya dalam mempengaruhi hasil belajar siswa. Hal ini terlihat dari hasil penelitiannya dimana $F_{\text {hitung }}=4,83>F_{\text {tabel }}=4,02$. Artinya terdapat hubungan yang signifikan antara peranan orang tua dan prestasi belajar PKn, dengan, (2) terdapat hubungan yang signifikan antara interaksi teman sebaya dan prestasi belajar PKn, dengan $F_{\text {hitung }}=9,55$ $>\mathrm{F}_{\text {tabel }}=4,02$, (3) terdapat hubungan yang signifikan secara bersama-sama antara prestasi belajar PKn dan peranan orang tua serta interaksi teman sebaya, dengan $F_{\text {hitung }}=$ $5,55>\mathrm{F}_{\text {tabel }}=3,17$. Berdasarkan hasil penelitian, disimpulkan bahwa peranan orang tua dan interaksi teman sebaya memengaruhi prestasi belajar siswa.

\section{Simpulan}

Berdasarkan analisis data dan pembahasan yang telah peneliti lakukan, dapat disimpulkan bahwa terdapat hubungan korelasi positif antara hasil belajar siswa dan keterampilan metakognitif siswa, dengan perolehan $\left(\mathrm{r}_{\text {hitung }}\right)=0,99$. Artinya semakin rendah nilai mahasiswa maka semakin tinggi prokrastinasi akademik mahasiswa, 
sebaliknya semakin tinggi nilai mahasiswa maka semakin rendah prokrastinasi akademik mahasiswa.

Berdasarkan hasil penelitian yang telah dilakukan peneliti menyarankan dalam melakukan penelitian sejenis, dosen ataupun guru hendaknya melakukan perencanaan, monitoring dan evaluasi secara mendetail dalam pelaksanaan penelitian guna menghindari bias ketika pengisian angket keterampilan metakognitif.

\section{Daftar Rujukan}

Arikunto. (2010). Manajemen Penulisan. Jakarta: Rineka Cipta.

Ganing, Y. (2015). Korelasi Antara Keterampilan Metakognitif dengan Hasil Belajar Biologi Siswa SP Negeri Kupang. Jurnal Biology Science \& Education 2015, 4(1), 40-49.

Gardner, H. (2004). Frames of Mind: The Theory of Multiple Intelligences. New York: Basic Books.

Hamalik, O. (2003). Perencanaan Pengajaran Berdasarkan Pendekatan Sistem. Jakarta: Bumi Aksara.

Haryati, F. (2015). Meningkatkan Kemandirian Belajar Siswa Melalui Pendekatan Metakognitif Berbasis Soft Skill. Suska Journal of Mathematics Education, 1(1).

Mujiono, D. (2013). Belajar dan Pembelajaran. Jakarta: PT. Rinceke Cipta.

Rindah, P. (2016). Pengembangan Perangkat Pembelajaran Berbasis self-regulated learning pada Materi keseimbangan lingkungan dan Perubahannya untuk meningkatkan Hasil belajar kognitif siswa. Jurnal Pendidikan Sains Pascasarjana Universitas Negeri Surabaya, 6(1).

Slameto. (2010). Belajar dan Faktor-faktor yang Mempengaruhinya. Jakarta: Rineka Cipta.

Sugihartono. (2007). Psikologi pendidikan. Yogyakarta: UNY Press.

Sugiyono. (2016). Metode Penelitian Pendidikan (pendekatan kuantitatif, kualitatif, dan $R \& D)$. Bandung: Alvababeta.

Wahyuni, R. sri. (2017). Peran Orangtua Terhadap Prestasi Siswakelas 5 Di Sd AlAzhar Syifabudi pekanbaru. Journal Endurance, 2(2), 18-24.

Yamin, M. (2013). Strategi dan Metode dalam Model Pembelajaran. Jakarta: Referensi (GP Press Group).

Yoel, M. (2016). Peningkatan Kemandirian Dan Hasil Belajar Matematika Melalui Strategi Metakognitif Berbasis Tutor Sebaya Bagi Siswa Kelas V Sd Ypk Persiapan Kampung Anny. Jurnal Surya LPPM Papua Jaya XIV. 